\title{
Evaluation of ruminal degradation profiles of forages using bags made from different textiles ${ }^{1}$
}

\section{Tiago Neves Pereira Valente ${ }^{2}$, Edenio Detmann ${ }^{3}$, Augusto César de Queiroz ${ }^{3}$, Sebastião de Campos Valadares Filho ${ }^{3}$, Daiany Iris Gomes ${ }^{2}$, Janderson Florêncio Figueiras ${ }^{2}$}

\footnotetext{
1 Pesquisa financiada pela FAPEMIG (PPM), CNPq and INCT-Ciência Animal.

2 Programa de Pós-Graduação em Zootecnia, Universidade Federal de Viçosa, Viçosa-MG. Pesquisador CNPq.

${ }^{3}$ Departamento de Zootecnia, UFV, Viçosa-MG. Pesquisador CNPq and INCT-Ciência Animal.
}

\begin{abstract}
The objective of this study was to evaluate the in situ degradation profiles of dry matter (DM) and neutral detergent fiber (NDF) of different forages using nylon $(50 \mu \mathrm{m})$, F57 $\left(\right.$ Ankom $\left.{ }^{\circledR}\right)$ and non-woven textile $\left(\mathrm{NWT}-100 \mathrm{~g} / \mathrm{m}^{2}\right)$ bags. Eight forage samples were used: sugarcane, corn silage, elephant grass cut at 50 and 250 days of regrowth, corn straw, signal grass hay, coast cross hay, and fresh alfalfa. Samples were incubated for 0, 3, 6, 12, 18, 24, 48, 72, 96, 120, 144, 168, 192, 216, 240, and 312 hours. Two bags of each textile were used at each incubation time, totaling 768 bags, using two crossbred Holstein $\times$ Zebu steers fitted with ruminal canullae. There was difference in the common rate of lag and degradation $(\lambda)$ of DM for all forages, except for sugarcane. In general, higher $\lambda$ estimates were obtained using nylon, followed by NWT and F57. Concerning NDF degradation profiles, differences in $\lambda$ were observed for all forages. Greater estimates were obtained using nylon. Degradation profiles of DM and NDF must not be evaluated using F57 and NWT. These textiles underestimate the degradation rate due to constraints regarding exchange between bags' content and rumen environment.
\end{abstract}

Key Words: F57, in situ method, non-woven textile, nylon

\section{Introduction}

The evaluation of digestion parameters in ruminant animals is assumed to be more accurate when in vivo methods are employed. However, several constraints, such as animal welfare and experimental costs, have been highlighted, and the interest in in situ or in vitro evaluations has increased (Broderick \& Cochran, 2000). Among those techniques, the in situ evaluations have been more recommended (Marinucci et al., 1992; Vanzant et al., 1998), noticeably because the measurements are performed in the rumen, where the degradation process is supposed to be more reliable than in vitro (Varel \& Kreikemeier, 1995). In addition, the in situ evaluation avoids the accumulation of final products of fermentation, which can affect degradation as sometimes observed under in vitro environments (Cherney et al., 1993).

On the other hand, the mathematical modeling of the in situ degradation profiles allows the estimation of different parameters of the rumen dynamics, including rate and extension of degradation, the effectively degraded fraction and the rumen fill effect of fiber (Vieira et al., 1997; Sampaio et al., 2009).

Different textiles have been suggested to make the bags used in the in situ evaluations, such as nylon $(50 \mu \mathrm{m})$,
F57 (Ankom ${ }^{\circledR}$ ) and non-woven textile (NWT, $100 \mathrm{~g} / \mathrm{m}^{2}$ ). Nevertheless, there is an imminent demand for results regarding consistency, accuracy and precision of estimates and for aspects concerning analytical costs and operational facilities of the different textiles (Casali et al., 2009).

In order to consider a textile useful for ruminal incubation, bags must present porosity thin enough to avoid loss of intact or non-degraded particles and be wide enough to allow the inflow of rumen fluid and microorganisms and the outflow of degradation products and to assure that microbial activity inside bags is similar to that observed in the ruminal environment (Nozière \& Michalet-Doreau, 2000; Ørskov, 2000). Some reports have brought into evidence that different textiles can affect the degradation estimates of feeds (Weakley et al., 1983; Figroid et al., 1972; Van Hellen \& Ellis, 1977; Huhtanen et al., 1994).

Nevertheless, information concerning analytical efficiency of textiles used for in situ evaluations is still scarce (Valente et. al., 2011a), noticeably concerning more recently developed textiles, such as NWT and F57.

The objective of this study was to evaluate the in situ degradation profiles of dry matter and neutral detergent fiber of different forages using bags made of nylon $(50 \mu \mathrm{m}), \mathrm{F} 57\left(\right.$ Ankom $\left.^{\circledR}\right)$ and non-woven textile (NWT $\left.-100 \mathrm{~g} / \mathrm{m}^{2}\right)$. 


\section{Material and Methods}

The experiment was carried out at the Laboratório de Nutrição Animal of the Departamento de Zootecnia at the Universidade Federal de Viçosa, Viçosa, Minas Gerais. Samples of eight forages were used: fresh sugarcane, corn silage, corn straw, signal grass hay, coast cross hay, fresh alfalfa, and fresh elephant grass cut at 50 and 250 days of regrowth. All samples were obtained in Viçosa, Minas Gerais.

Samples of corn silage, sugarcane, elephant grass and alfalfa were oven-dried $\left(60{ }^{\circ} \mathrm{C}\right)$ and, along with other samples, processed in a knife mill to pass through 1- and 2-mm screen sieves.

Chemical evaluations were performed using samples processed at $1 \mathrm{~mm}$. The contents of dry matter (DM), organic matter and crude protein (CP) were evaluated according to Silva \& Queiroz (2002). The contents of neutral detergent fiber (NDF) were evaluated using the detergent composition recommended by Mertens (2002), using a fiber analyzer (Ankom $\left.{ }^{220}\right)$. NDF analysis was conducted using a heat-stable á-amilase (Termamyl 2X, Novozymes), but not sodium sulfite. There were no ash or protein corrections on NDF contents (Table 1).

For the evaluation of DM and NDF degradation profiles, bags of $4 \times 5 \mathrm{~cm}$ were manufactured using nylon $(50 \mu \mathrm{m})$ and NWT $\left(100 \mathrm{~g} / \mathrm{m}^{2}\right)$. The F57 bags were bought directly from the manufacturer $\left(\right.$ Ankom $\left.^{\circledR}\right)$. Samples were put in the bags following the ratio of $20 \mathrm{mg} \mathrm{DM} / \mathrm{cm}^{2}$ of surface (Nocek, 1988). For all experimental procedures, bags were heatsealed. The following incubations times were evaluated: 0 , $3,6,12,18,24,48,72,96,120,144,168,192,216,240$, and 312 hours. Two bags of each textile in each incubation time were evaluated for each forage, totaling 768 bags.

Incubations were performed using two rumen fistulated Holstein $\times$ Zebu steers. Animals were fed a mixed diet which presented an 80:20 forage to concentrate ratio and $12 \%$ of $\mathrm{CP}$ as DM basis. One bag of each textile in each incubation time was attached to each animal. Incubation times were evaluated in a reverse order so all bags were taken from the rumen at same time. After that, bags were cleaned with tap water, oven-dried $\left(60^{\circ} \mathrm{C} / 72\right.$ hours followed by $105^{\circ} \mathrm{C} / 1$ hour), put in a dissecator and then weighed (Detmann et al., 2001), to obtain the non-degraded residue of DM.

The procedures to evaluate NDF contents were performed by using a fiber analyzer $\left(\right.$ Ankom $\left.^{220}{ }^{\circledR}\right)$. After neutral detergent extraction, bags were washed sequentially with hot distilled water and acetone, oven-dried $\left(60^{\circ} \mathrm{C} / 72\right.$ hours followed by $105^{\circ} \mathrm{C} / 1$ hour), put in a dissecator and then weighed to obtain the non-degraded residue of NDF.

Before incubation procedures, all bags were cleaned with boiling neutral detergent solution, oven-dried and weighed as described before to obtain the blank weights.

The degraded fractions of DM were interpreted independently for each textile and forage as a function of incubation time using a non-linear logistic model adapted from suggestions of Van Milgen et al. (1991):

$$
D_{t}=A+B \times[1-(1+\lambda \times t) \times \exp (-\lambda \times t)]
$$

where: $D_{t}=$ degraded fraction of DM after $t$ hours of incubation (\%); $\mathrm{A}=$ soluble fraction (\%); $\mathrm{B}=$ insoluble but potentially degradable fraction (\%); and $\lambda=$ common fractional rate of lag and degradation $\left(\mathrm{h}^{-1}\right)$.

Similarly, the non-degraded residues of NDF were evaluated by adjusting the non-linear logistic model of Van Milgen et al. (1991):

$$
\left.R_{t}=B \times(1+\lambda \times t) \times \exp (-\lambda \times t)\right]+U
$$

where: $\mathrm{R}_{\mathrm{t}}=$ non-degraded residue of NDF after $\mathrm{t}$ hours of incubation (\%); $\mathrm{B}=$ potentially degradable fraction (\%); $\mathrm{U}=$ undegradable fraction (\%); and $\lambda=$ common fractional rate of lag and degradation $\left(\mathrm{h}^{-1}\right)$.

The comparison between textiles was performed independently for each forage by using the $\chi^{2}$ distribution according the non-linear models identity test of Regazzi (2003). The statistical evaluations were individually applied to the parameters described in Equations (1) and (2). In this case, two different tests were performed: difference among all textiles and difference between F57 and NWT.

\begin{tabular}{|c|c|c|c|c|}
\hline \multirow[b]{2}{*}{ Feed } & \multicolumn{4}{|c|}{ Item } \\
\hline & $\begin{array}{c}\text { Dry matter, DM } \\
(\% \text { as is })\end{array}$ & $\begin{array}{l}\text { Organic matter } \\
\left(\begin{array}{l}\% \\
\%\end{array}\right)\end{array}$ & $\begin{array}{l}\text { Crude protein } \\
\qquad(\% \text { DM })\end{array}$ & $\begin{array}{c}\text { Neutral detergent fiber } \\
\left(\begin{array}{ll}\% & D M\end{array}\right)\end{array}$ \\
\hline Sugarcane & 22.28 & 96.33 & 2.90 & 60.41 \\
\hline Corn silage & 30.97 & 93.06 & 4.49 & 57.79 \\
\hline Elephant grass (50 days) & 13.55 & 92.17 & 9.07 & 74.35 \\
\hline Elephant grass (250 days) & 22.54 & 93.54 & 7.20 & 85.34 \\
\hline Corn straw & 90.43 & 98.50 & 1.88 & 90.80 \\
\hline Signal grass hay & 90.54 & 96.59 & 3.71 & 86.29 \\
\hline Coast cross hay & 89.96 & 94.41 & 11.43 & 83.93 \\
\hline Alfalfa & 25.31 & 90.70 & 21.96 & 49.50 \\
\hline
\end{tabular}

Table 1 - Chemical composition of feeds 
To evaluate the loss of fibrous particles, the nondegraded residues of NDF were transformed in degraded fractions and submited to adjustment the the reciprocal of the model described by Equation (2), which corresponds to Equation (1). After that, the limits of the asymptotic confidence interval $(1-\alpha=0.95)$ for the parameter A (Equation 1) were estimated. The loss of fibrous particles was assumed to be non-significant $(\mathrm{P}>0.05)$ when zero was included in the confidence interval.

The critical times to reach the asymptote were estimated through the method developed by Casali et al. (2008). Such estimates were iteratively obtained when the degraded fraction of DM and the non-degraded fraction of NDF become equivalent to the values (Figure 1):

$$
\begin{aligned}
& D c=A+L(B) \\
& R C=U(U)
\end{aligned}
$$
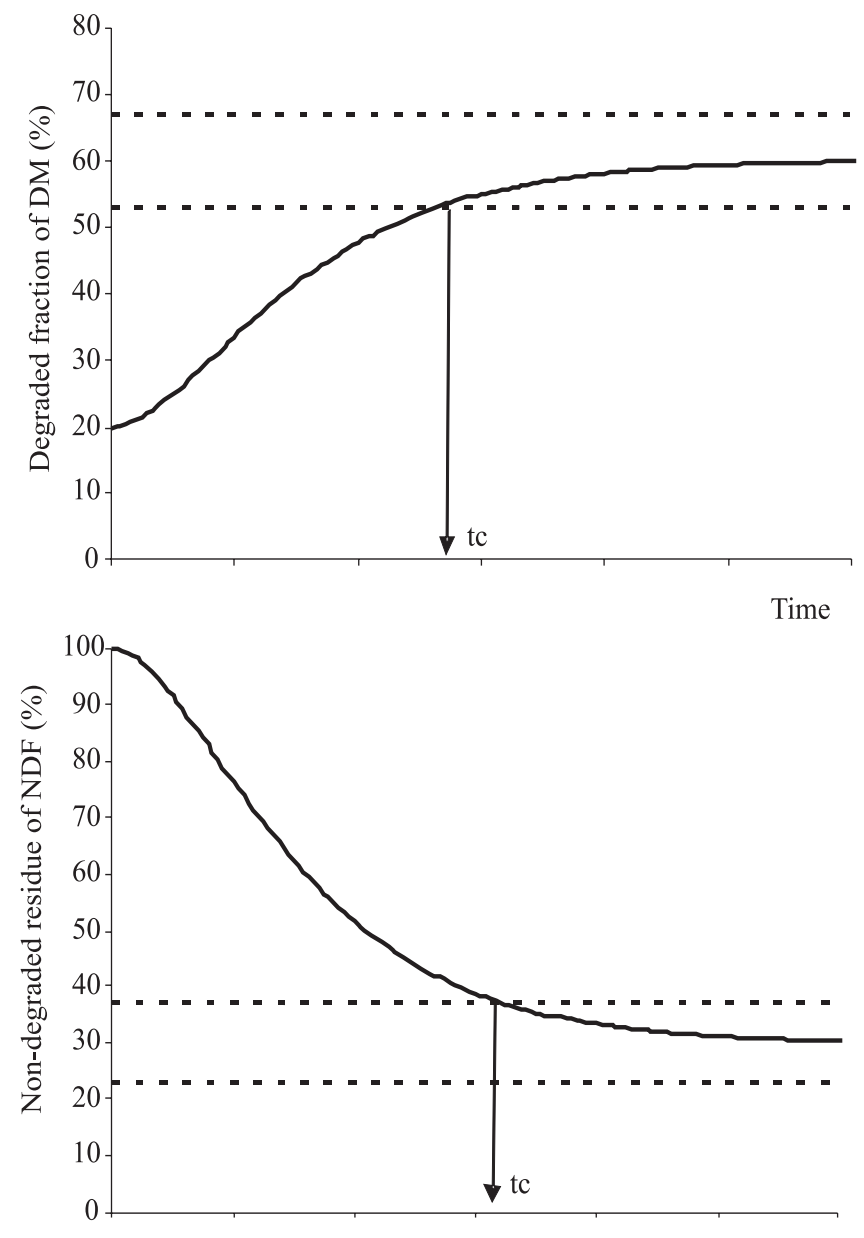

Time

Figure 1 - Example of ruminal degradation profiles of dry matter (DM) and neutral detergent fiber (NDF) as functions of incubation time (The dashed lines represent the limits of asymptotic confidence intervals; $t c=$ critical time to reach the asymptote with an asymptotic confidence level of $1-\alpha$ ). where: Dc = estimate of degraded fraction of DM occurring in the intersection between the fitted degradation profile and the lower limit of asymptotic confidence interval of insoluble but potentially degradable fraction of DM added to soluble fraction $(\%) ; \mathrm{A}=$ soluble fraction of $\mathrm{DM}(\%) ; \mathrm{L}(\mathrm{B})=$ lower limit of asymptotic confidence interval $(1-\alpha=0.95)$ of the insoluble but potentially degradable fraction of DM (\%); $\mathrm{Rc}=$ estimate of non-degraded fraction of NDF occurring in the intersection point between the fitted degradation profile and the upper limit of asymptotic confidence interval of undegradable fraction of NDF (\%); and $\mathrm{U}(\mathrm{U})=$ upper limit of asymptotic confidence interval $(1-\alpha=0.95)$ of undegradable fraction of NDF $(\%)$.

All statistical procedures were performed using SAS (Statistical Analysis System 9.1) adopting 0.05 as the critical level of asymptotic probability for type I error.

\section{Results and Discussion}

When all textiles were compared, differences in soluble fraction of $\mathrm{DM}(\mathrm{P}<0.05)$ were found only for corn silage and corn straw (Table 2), with higher estimates obtained with nylon (Table 3 ). In addition, differences among textiles regarding insoluble but potentially degradable fraction of DM were observed $(\mathrm{P}<0.05)$ for sugarcane, corn straw and alfalfa (Table 2). Is this case, lower estimates were obtained with F57 (Table 3). Differences among textiles concerning

Table 2 - Descriptive levels of asymptotic probability of type I error for the comparison between textiles concerning parameters of dry matter degradation

\begin{tabular}{lccr}
\hline & \multicolumn{3}{c}{ Parameter $^{2}$} \\
\cline { 2 - 4 } Forage $^{1}$ & \multicolumn{1}{c}{$\mathrm{A}$} & $\mathrm{B}$ & \multicolumn{1}{c}{$\lambda$} \\
\hline & \multicolumn{3}{c}{ Comparison among all textiles } \\
SC & 0.2377 & 0.0130 & 0.2526 \\
CSIL & 0.0011 & 0.4340 & 0.0325 \\
EG50 & 0.0539 & 0.0935 & $<0.0001$ \\
EG250 & 0.1275 & 0.1389 & 0.0008 \\
CST & 0.0413 & 0.5772 & 0.0258 \\
SGH & 0.1209 & 0.0115 & 0.0019 \\
CH & 0.8494 & 0.3266 & $<0.0001$ \\
ALF & 0.8415 & 0.0018 & $<0.0001$ \\
& & & \\
SC & 0.5174 & 0.0210 & 0.6969 \\
CSIL & 0.5114 & 0.2199 & 0.2896 \\
EG50 & 0.0273 & 0.5846 & 0.3623 \\
EG250 & 0.1945 & 0.0406 & 0.2022 \\
CST & 0.5421 & 0.3218 & 0.2137 \\
SGH & 0.1346 & 0.1358 & $>0.9999$ \\
CH & 0.7007 & 0.3890 & 0.0010 \\
ALF & 0.8963 & 0.0187 & 0.0039 \\
\hline
\end{tabular}

${ }^{1} \mathrm{SC}=$ sugarcane; $\mathrm{CSIL}=$ corn silage; $\mathrm{EG} 50=$ elephant grass cut at 50 days of regrowth; EG250 = elephant grass cut at 250 days of regrowth; $\mathrm{CST}=$ corn straw; $\mathrm{SGH}=$ signal grass hay; $\mathrm{CH}=$ coast cross hay; and $\mathrm{ALF}=$ alfalfa.

${ }^{2} \mathrm{~A}=$ soluble fraction; $\mathrm{B}=$ insoluble but potentially degradable fraction; $\lambda=$ common rate of lag and degradation. 
Table 3 - Degradation parameters of dry matter according to forages and textiles

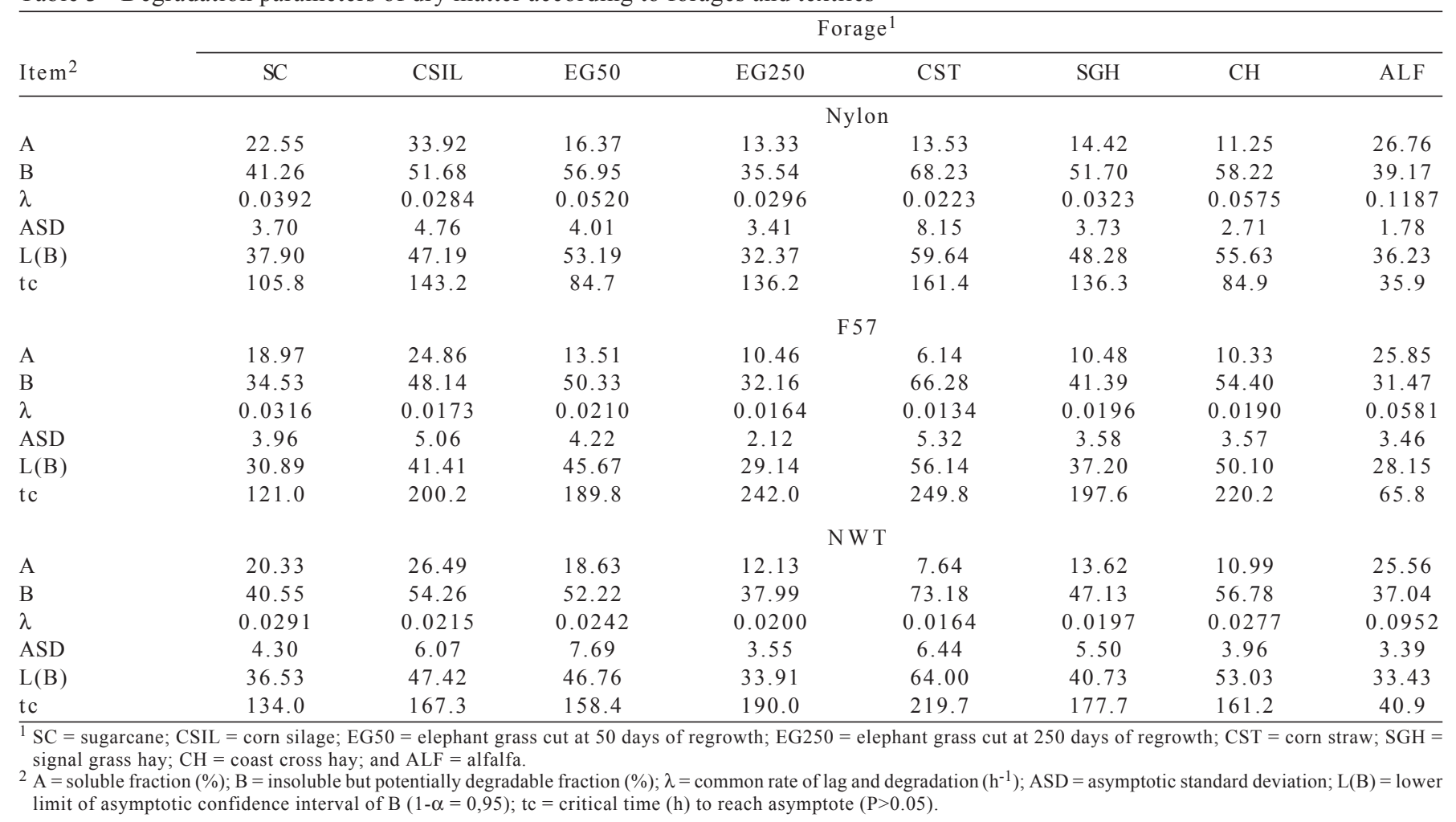

parameter $\lambda$ were observed for all forages $(\mathrm{P}<0.05)$ with exception of sugarcane $(\mathrm{P}>0.05)$. Generally, greater estimates were obtained by using nylon (Table 3 ; Figure 2 ).

F57 and NWT present similar physical structure and both textiles are produced by deposition of synthetic fiber without weaving (Casali et al., 2009; Valente et al., 2011a). Recently, it has been proposed that NWT could replace F57 in laboratorial analysis of fiber and in procedures for in situ evaluation of indigestible compounds in feeds and cattle

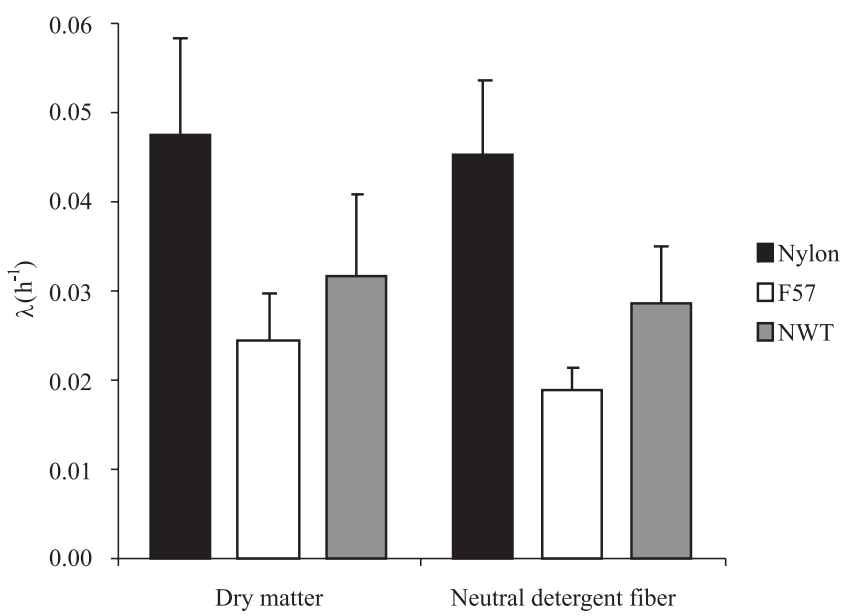

Figure 2 - Average estimates of common rate of lag and degradation $(\lambda)$ of dry matter and neutral detergent fiber according to different textiles. feces. That statement was based on similar accuracy between textiles and lower cost of NWT compared with F57 (Valente et al., 2011a;2011b). Facing such perspectives, the comparison between these textiles was performed.

Differences between F57 and NWT regarding soluble fraction of DM were observed $(\mathrm{P}<0.05)$ only for elephant grass cut at 50 days of regrowth (Table 2), with the greatest estimate obtained with NWT (Table 3). Higher estimates of insoluble but potentially degradable fraction were observed $(\mathrm{P}<0.05)$ when sugarcane, elephant grass (250 days) and alfalfa were evaluated with NWT (Table 3 ). Concerning parameter $\lambda$, lower estimates $(\mathrm{P}<0.05)$ were obtained with F57 for coast cross hay and alfalfa, but there were no differences $(\mathrm{P}>0.05)$ for the other forages (Table 3$)$.

The non-degraded residues of DM can present some variation inherent to evaluation process. Those could be associated with lack of standardization of washing bags procedures after removal from the rumen (Cherney et al., 1990; Vanzant et al., 1998) or due to presence of microbial contaminants (Huhtanen et al., 1994; Casali et al., 2009) which could not be homogeneous among replicates (Sampaio et al., 2011). Thereby, the comparison between degradation profiles of DM obtained with different textiles could present low precision attributed to influence of external factors. On the other hand, such biases are not expected to affect NDF degradation because the extraction with anionic 
detergent withdraws contaminants such as microbial debris (Van Soest, 1994). Accordingly, better understanding of the effects of the different textiles on DM degradation parameters may be obtained when NDF degradation is simultaneously evaluated.

When all textiles were compared, differences concerning $B$ fraction of NDF (potentially degradable fraction) were observed $(\mathrm{P}<0.05)$ for sugarcane, elephant grass (50 days) and alfalfa (Table 4) with the highest estimates obtained with nylon (Table 5). Concerning the $\mathrm{U}$ fraction (undegradable fraction), differences were observed $(\mathrm{P}<0.05)$ for the forages cited above plus corn straw and coast cross hay (Table 4). Lower estimates of $U$ fraction were verified with nylon (Table 5). Differences concerning parameter $\lambda$ were detected $(\mathrm{P}<0.05)$ for all forages (Table 4). On average, higher estimates were obtained with nylon (Table 5; Figure 2).

No difference $(\mathrm{P}>0.05)$ was verified for $\mathrm{B}$ and $\mathrm{U}$ fractions when F57 and NWT were compared (Table 4). Such pattern allows inferring that differences regarding fraction sizes would be attributed only to the differences between nylon and the textiles obtained without weaving (NWT and F57).

On the other hand, differences concerning parameter $\lambda$ were observed between NWT and F57 $(\mathrm{P}<0.05)$ for corn silage, elephant grass ( 250 days), coat cross hay and alfalfa (Table 4). For those forages, higher estimates were verified by using NWT (Table 5; Figure 2).

The evaluation of soluble fraction of NDF presents a different interpretation compared with that done for DM because NDF is insoluble in neutral medium such as ruminal environment. Thereby, there is not a true soluble fraction of NDF (Detmann, 2010). From this statement, the evaluation of apparently soluble NDF by using the reciprocal of the model adopted to interpret NDF degradation (Equation 1) must be understood as a method to evaluate the loss of fibrous particles through textile apertures.

All textiles allowed loss of fibrous particles $(\mathrm{P}<0.05)$; with the exception of $(\mathrm{P}>0.05)$ elephant grass (50 days) when F57 was used; corn silage when F57 and NWT were used; and alfalfa, which did not present losses with any textile (Table 5).

One of the main constraints for using textiles in the evaluation of insoluble fibrous compounds is the possibility of particle loss during analytical procedures (Hvelpund \& Weisbjerg, 2000; Casali et al., 2009; Valente et al., 2011a). In this context, when samples are processed to be used in incubation procedures, one must seek for a particle size that represents an equilibrium point between control of particles loss and an adequate specific surface for microbial degradation (Valente et al., 2011a).
The particle size used in this research is that currently recommended for in situ evaluation of feeds (Vanzant et al., 1998; Nozière \& Michaelet-Doreau, 2000; NRC, 2001). However, the true particle size after grinding may be different for each material (Nozière \& Michaelet-Doreau, 2000). Thereby, for some materials, the grinding to pass through a 2-mm screen sieve can produce particles thin enough to escape through textile before degradation. This assumption seems to support the variability among feeds concerning loss of fibrous particles (Table 5).

Differences in soluble fraction of DM were detected only for two roughages (Table 2). Despite this, the evaluation of loss of fibrous particles brought into evidence that those are more prominent by using nylon (Figure 3). Such pattern seems to be, at least partially, the cause of the lower estimates of potentially degradable fraction of NDF when nylon was used (Figure 3) and could directly affect the estimates of DM fractions (Tables 2 and 3). The broader porosity of nylon has been considered the main cause of its greater losses of particles (Casali et al., 2009; Valente et al., 2011a).

Moreover, despite the differences concerning fractions, the more evident difference between degradation profiles obtained with the different textiles must be attributed to the estimates of degradation rates (Tables 2, 3, 4 and 5; Figure 2).

Table 4 - Descriptive levels of asymptotic probability of type I error for the comparison between textiles concerning parameters of neutral detergent fiber degradation

\begin{tabular}{|c|c|c|c|}
\hline \multirow[b]{2}{*}{ Forage } & \multicolumn{3}{|c|}{ Parameter } \\
\hline & A & $\mathrm{B}$ & $\lambda$ \\
\hline & \multicolumn{3}{|c|}{ Comparison among all textiles } \\
\hline $\mathrm{SC}$ & 0.0390 & 0.0012 & 0.0189 \\
\hline CSIL & 0.8504 & 0.8847 & $<0.0001$ \\
\hline EG50 & 0.0339 & 0.0223 & $<0.0001$ \\
\hline EG250 & 0.4473 & 0.1940 & $<0.0001$ \\
\hline CST & 0.5132 & 0.6791 & $<0.0001$ \\
\hline SGH & 0.1349 & 0.0144 & 0.0005 \\
\hline $\mathrm{CH}$ & 0.2815 & 0.0406 & 0.0001 \\
\hline \multirow[t]{2}{*}{ ALF } & 0.0116 & $<0.0001$ & $<0.0001$ \\
\hline & \multicolumn{3}{|c|}{ Comparison between NWT and F57 } \\
\hline $\mathrm{SC}$ & 0.1316 & 0.0538 & 0.8289 \\
\hline CSIL & 0.9045 & 0.9609 & 0.0214 \\
\hline EG50 & $>0.9999$ & 0.1937 & 0.2393 \\
\hline EG250 & 0.1938 & 0.1292 & 0.0010 \\
\hline CST & 0.4591 & 0.3740 & 0.1395 \\
\hline $\mathrm{SGH}$ & 0.3935 & 0.1356 & 0.8018 \\
\hline $\mathrm{CH}$ & 0.6350 & 0.3405 & 0.0011 \\
\hline ALF & $>0.9999$ & 0.4236 & $<0.0001$ \\
\hline
\end{tabular}

R. Bras. Zootec., v.40, n.11, p.2565-2573, 2011 
The concept of critical time to reach the asymptote was proposed by Casali et al (2009) as a probabilistic approach to obtain estimates of undegradable fractions by using a single incubation time, noticeably when those fractions are used as internal markers.

Firstly, nylon is not recommended for this procedure (Casali et al., 2009; Valente et al., 2011a) because it propitiates great loss of fibrous particles (Figure 3). From this, direct comparisons for evaluating the estimation procedures of undegradable compounds must be done between F57 and NWT. The average critical times were greater for F57 when compared with NWT (Figure 4). The maximal estimates of critical times were 249.8 and 219.7 hours for DM and 274.5 and 227.7 hours for NDF, considering F57 and NWT, respectively (Tables 3 and 5). The maximal estimates of critical times obtained with NWT agrees with the propositions of Casali et al. (2008), who recommended ruminal incubation for 240 hours to estimate the undegradable fraction of DM and NDF by using NWT bags. However, according to the results of this study, such recommendation seems not to be valid when F57 is used. By considering the maximal estimate of critical time for NDF (274.5 hours) and adopting a multiple of 24 hours to build an analytical recommendation, it will be necessary at least 288 hours ( 12 days) to obtain a reliable estimate of undegradable fraction of NDF when F57 bags are used.

Secondly, the greater critical times obtained with F57 and NWT compared with nylon (Figure 4) were directly caused by lower degradation rates (Figure 2). Initially, the higher degradation rates obtained with nylon could be attributed to a greater loss of particles during initial incubation times. However, there was a little difference between textiles concerning loss of fibrous particles (Figure 3). Thereby, there is no evidence enough to support the loss of particles as the sole or the main cause of differences concerning degradation rates.

The structure of porosity of NWT and F57 is not regular because textiles are made by deposition of fibers without

Table 5 - Degradation parameters of neutral detergent fiber according to forages and textiles

\begin{tabular}{|c|c|c|c|c|c|c|c|c|}
\hline \multirow[b]{2}{*}{ Item $^{2}$} & \multicolumn{8}{|c|}{ Forage $^{1}$} \\
\hline & $\mathrm{SC}$ & CSIL & EG50 & EG250 & CST & SGH & $\mathrm{CH}$ & ALF \\
\hline & \multicolumn{8}{|c|}{ Nylon } \\
\hline U & 39.41 & 16.62 & 26.58 & 52.94 & 16.73 & 32.09 & 28.66 & 57.00 ëë \\
\hline$\lambda$ & 0.0417 & 0.0258 & 0.0523 & 0.0285 & 0.0287 & 0.0317 & 0.0602 & 0.0941 \\
\hline ASD & 3.72 & 6.13 & 3.85 & 3.61 & 6.34 & 3.81 & 2.52 & 2.12 \\
\hline $\mathrm{U}(\mathrm{A})$ & 11.38 & 10.64 & 6.52 & 8.26 & 13.80 & 11.01 & 7.37 & 3.34 \\
\hline $\mathrm{L}(\mathrm{A})$ & 5.63 & 2.20 & 0.14 & 3.18 & 4.87 & 5.48 & 3.01 & -0.82 \\
\hline \multirow[t]{2}{*}{$\mathrm{tc}$} & 117.7 & 170.6 & 101.9 & 157.4 & 154.1 & 154.4 & 96.4 & 58.7 \\
\hline & \multicolumn{8}{|c|}{ F 57} \\
\hline B & 44.11 & 80.45 & 62.19 & 37.51 & 73.87 & 51.86 & 62.14 & 35.61 \\
\hline U & 50.53 & 19.37 & 35.85 & 59.47 & 22.15 & 44.33 & 33.98 & $63.56 \mathrm{ë}$ \\
\hline $\mathrm{U}(\mathrm{A})$ & 8.96 & 3.55 & 4.91 & 4.88 & 7.64 & 6.38 & 6.35 & 3.12 \\
\hline $\mathrm{L}(\mathrm{A})$ & 1.76 & -3.20 & -1.00 & 1.14 & 0.32 & 1.22 & 1.42 & -1.47 \\
\hline \multirow[t]{2}{*}{ tc } & 149.2 & 274.5 & 214.9 & 209.2 & 249.3 & 217.7 & 219.5 & 145.2 \\
\hline & \multicolumn{8}{|c|}{ NW T } \\
\hline B & 49.33 & 79.37 & 62.36 & 41.78 & 79.38 & 55.93 & 63.52 & 35.75 \\
\hline U & 43.99 & 18.84 & 30.40 & 54.19 & 15.22 & 36.85 & 31.36 & 62.14 \\
\hline$\lambda$ & 0.0277 & 0.0162 & 0.0227 & 0.0246 & 0.0162 & 0.0189 & 0.0289 & 0.0730 \\
\hline ASD & 5.34 & 7.26 & 6.46 & 3.50 & 6.35 & 6.69 & 4.53 & 4.36 \\
\hline $\mathrm{U}(\mathrm{U})$ & 48.17 & 29.49 & 36.50 & 57.24 & 24.53 & 44.70 & 34.78 & 64.36 \\
\hline A & 6.68 & 1.78 & 7.24 & 4.02 & 5.40 & 7.72 & 5.12 & 2.12 \\
\hline $\mathrm{U}(\mathrm{A})$ & 10.42 & 6.41 & 11.59 & 6.42 & 9.45 & 11.59 & 8.32 & 6.05 \\
\hline$L(A)$ & 2.95 & -2.84 & 2.89 & 1.63 & 1.35 & 2.85 & 1.93 & -1.82 \\
\hline
\end{tabular}


weaving. Thereby, these textiles show thinner porosity compared with nylon (Casali et al., 2009; Valente et al., 2011a). Very thin porosities can compromise the withdrawal of fermentation gases from the bags inside, which can restrict the microbial access to the substrate and, as a consequence, decrease degradation, noticeably at initial incubation times (Udén et al., 1974; Udén \& Van Soest, 1984). Such events could lead to lower degradation rates, such as observed in this study (Figure 5).

One of the desirable characteristics of a textile used to evaluate ruminal degradation lies on its capacity to allow the inflow of ruminal fluid and microorganisms and, at same time, allow the outflow of the degraded material (Varvikko \& Vanhatalo, 1990; Nozière \& Michalet-Doreau, 2000). Problems concerning this characteristic can affect the slope of degradation curves (Nocek, 1988); as it was seen in this research (Figure 5). The thinning of bag porosity can

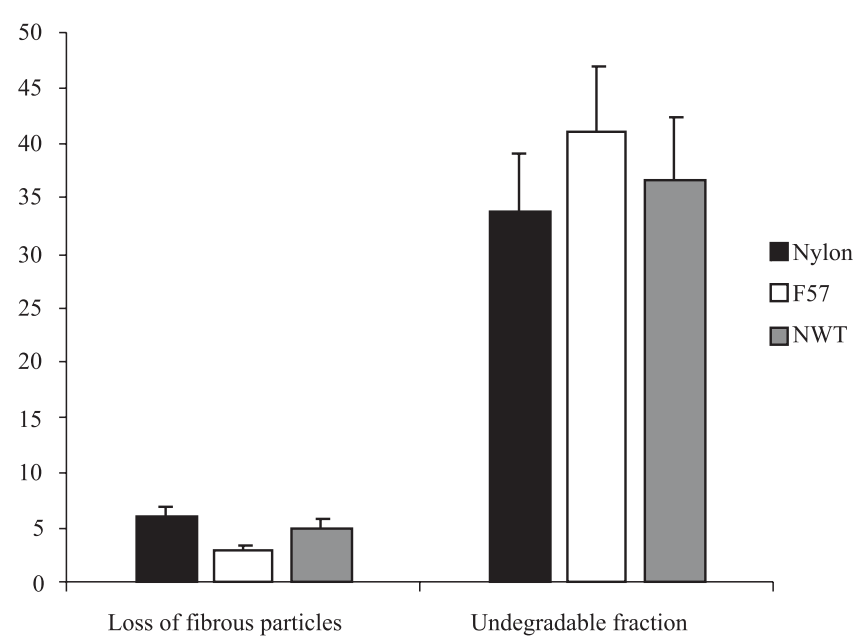

Figure 3 - Average estimates of fibrous particles loss (\%) and undegradable fraction of neutral detergent fiber (\%) according to different textiles.

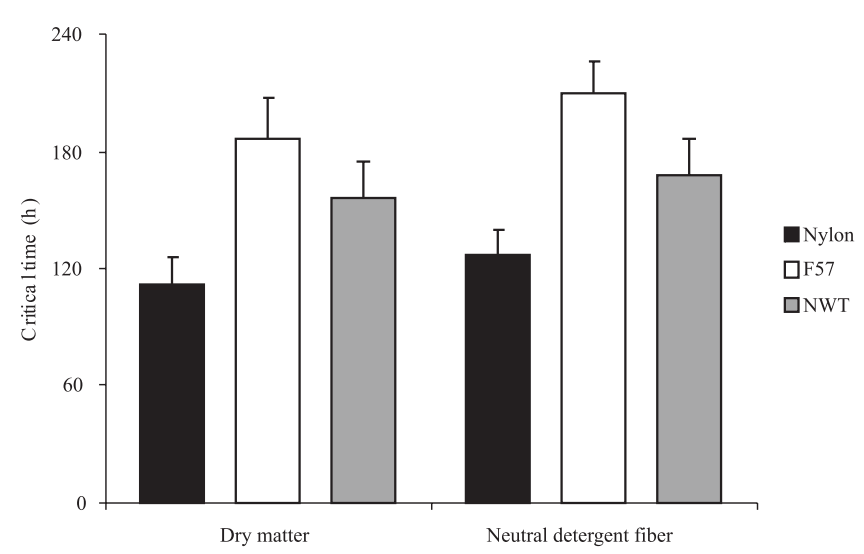

Figure 4 - Average estimates of critical time to reach the asymptote for dry matter and neutral detergent fiber according to different textiles (See details in Equations 3 and 4 and Figure 1). decrease the entering of microorganisms (Lindberg et al., 1984) and enhance the differences between microbial populations inside and outside the bags (Nozière \& MichaletDoreau, 2000).

Less prominent differences concerning degradation rate were observed between NWT and F57 (Tables 2 and 4). On average, greater degradation rates were obtained with NWT (Figure 2), which propitiates lower critical times with this textile (Figure 4). When incubated in the rumen, NWT presents loss of physical resistance, which does not occur with F57 (Valente et al., 2011a). Thereby, such resistance loss can make NWT more susceptible to the exchanges with rumen environment, compared with F57, generating greater estimates of degradation rates with NWT compared with F57, but still being lower than nylon (Figure 5). On the other hand, the greater critical times obtained with F57 compared with NWT seem to indicate that degradation profiles obtained with F57 could not be completely stabilized, even considering the long term incubation used in this study (Figure 5).
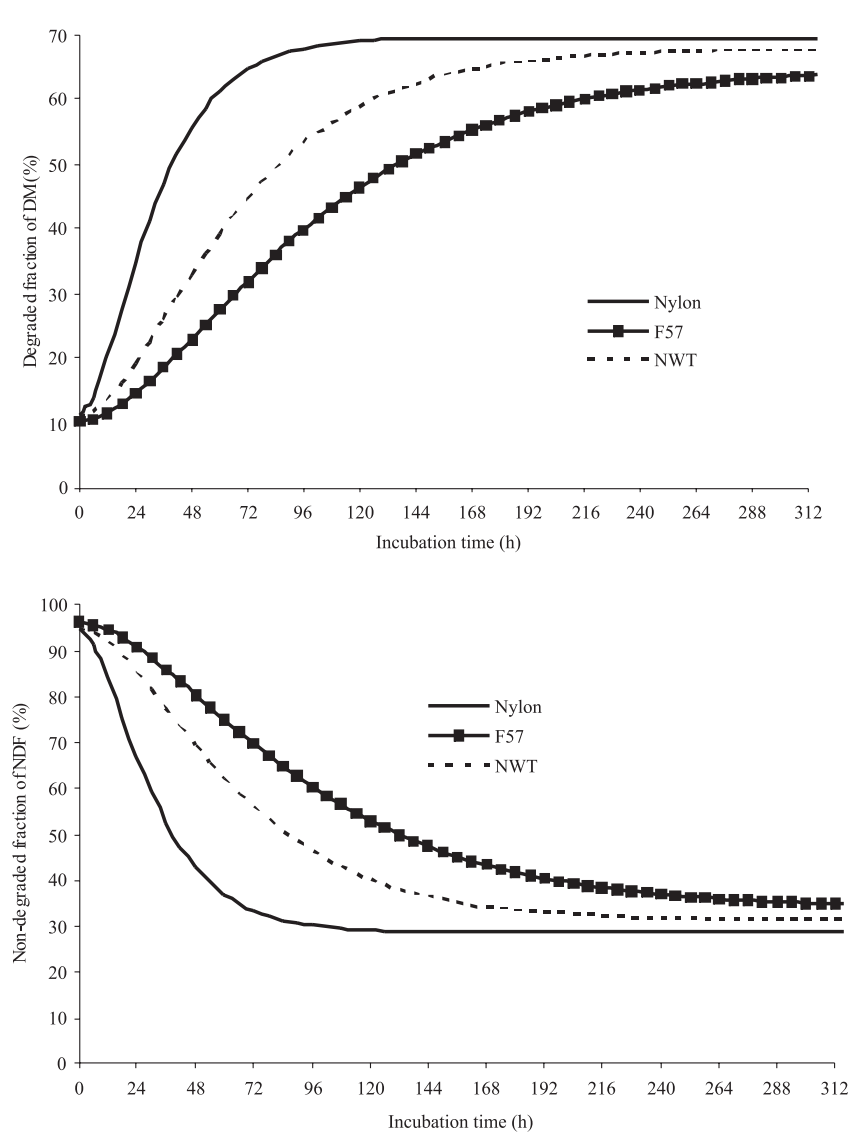

Figure 5 - Fitted degradation profiles of dry matter (DM) and neutral detergent fiber (NDF) of coast cross hay according to the different textiles (see details of parameters in Tables 3 and 5). 
For some forages, the degradation rates (which are represented by parameter $\lambda$ ) were extremely low when F57 and NWT were used (e.g., elephant grass cut at 50 days of regrowth). Such estimates should be considered near to a biological incoherence (Tables 3 and 5). Corrections or adjustments on degradation profile concerning loss of particles are possible (Nozière \& Michalet-Doreau, 2000) but this is not true concerning underestimation of degradation rate.

Considering nylon as the standard textile to perform degradation procedures (Hvelplund \& Weisbjerg, 2000; NRC, 2001), the utilization of NWT and F57 to estimate parameters of ruminal degradation dynamics is not recommended.

\section{Conclusions}

Ruminal degradation profiles of dry matter and neutral detergent fiber must not be obtained by using F57 and nonwoven textile (NWT, $100 \mathrm{~g} / \mathrm{m}^{2}$ ), for there are constraints regarding exchange of material with ruminal environment that underestimate degradation rates. The estimation of undegradable fraction using a single incubation time must be done for 240 and 288 hours using NWT and F57, respectively. Studies where estimates of dry matter and neutral detergent fiber degradation parameters and ruminal digestibility coefficients are concomitantly obtained are still necessary in order to obtain more accurate comparison among textiles.

\section{References}

BRODERICK, G.A.; COCHRAN, R.C. In vitro and in situ methods for estimating digestibility with reference to protein degradability. In: THEODOROU, M.K.; FRANCE, J. (Eds.). Feeding systems and feed evaluation models. Wallingford: CAB International, 2000. p.53-85.

CASALI, A.O.; DETMANN, E.; VALADARES FILHO, S.C. et al. Influência do tempo de incubação e do tamanho de partículas sobre os teores de compostos indigestíveis em alimentos e fezes bovinas obtidos por procedimentos in situ. Revista Brasileira de Zootecnia, v.37, p.335-342, 2008.

CASALI, A.O.; DETMANN, E.; VALADARES FILHO, S.C. et al. Estimação de teores de componentes fibrosos em alimentos para ruminantes em sacos de diferentes tecidos. Revista Brasileira de Zootecnia, v.38, p.130-138, 2009.

CHERNEY, D.J.R.; PATTERSON, J.A.; LEMENAGER, R.P. Influence of in situ bag rising technique on determination of dry matter disappearance. Journal of Dairy Science, v.73, p.391-397, 1990.

CHERNEY, D.J.R.; SICILIANO-JONES, J.; PELL, A.N. Forage in vitro dry matter digestibility as influenced by fiber source in the donor cow diet. Journal of Animal Science, v.71, p.1335-1338, 1993.

DETMANN, E. Fibra na nutrição de novilhas leiteiras. In: PEREIRA, E.S.; PIMENTEL, P.G.; QUEIROZ, A.C. et al. (Eds.) Novilhas leiteiras. Fortaleza: Graphiti, 2010. p.253-302.
DETMANN, E.; PAULINO, M.F.; ZERVOUDAKIS, J.T. et al. Cromo e indicadores internos na determinação do consumo de novilhos mestiços, suplementados, a pasto. Revista Brasileira de Zootecnia, v.30, p.1600-1609, 2001.

FIGROID, W.; HALE, W. H.; THEURER, B. An evaluation of the nylon bag technique for estimating rumen utilization of grains. Journal of Animal Science, v.35, p.113-120, 1972.

HUHTANEN, P., KAUSTELL, K., JAAKKOLA, S. The use of internal markers to predict digestibility and duodenal flow of nutrients in cattle given six different diets. Animal Feed Science and Technology, v.48, p.211-227, 1994.

HVELPLUND, T; WEISBJERG, M.R. In situ techniques for the estimation of protein degradability and post rumen availability In: GIVENS, D.I.; OWEN, E.; AXFORD, R.F.E. et al. (Eds.) Roughage evaluation in ruminant nutrition. London: $C A B$ International, 2000. p.233-258.

LINDBERG, J.E.; KASPERSSON, A.; CISZUK, P. Studies on pH, number of protozoa and microbial ATP concentrations in rumen-incubated nylon bags with different pore sizes. Journal of Agricultural Science, v.102, p.501-504, 1984

MARINUCCI, M.T.; DEHORITY, B.A.; LOERCH, S.C. In vitro and in vivo studies of factors affecting digestion of feeds in synthetic fiber bags. Journal of Animal Science, v.70, p.296-307, 1992.

MERTENS, D.R. Gravimetric determination of amylase-treated neutral detergent fiber in feeds with refluxing in beaker or crucibles: collaborative study. Journal of AOAC International, v.85, p.1217-1240, 2002.

NATIONAL RESEARCH COUNCIL - NRC. Nutrient requirements of dairy cattle. 7.ed. Washington, DC: Academic Press, 2001. $381 \mathrm{p}$.

NOCEK, J.E. In situ and other methods to estimate ruminal protein and energy digestibility: a review. Journal of Dairy Science, v.71, p.2051-2069, 1988.

NOZIĖRE, P.; MICHALET-DOREAU, B. In sacco methods. In: D'MELLO, J.P.F. (Ed.) Farm animal metabolism and nutrition. London: CAB International, 2000. p.233-253.

ØRSKOV, E.R. The in situ technique for the estimation of forage degradability in ruminants. In: GIVEN, D.I.; OWENS, E.; AXFORD, R.F.E. et al. (Eds.). Forage evaluation in ruminant nutrition. Wallingford: CAB International, 2000. p.175-188.

REGAZZI, A.J. Teste para verificar a igualdade de parâmetros e a identidade de modelos de regressão não linear. Ceres, v. 50 , p.9-26, 2003.

SAMPAIO, C.B.; DETMANN, E.; LAZZARINI, I. et al. Rumen dynamics of neutral detergent fiber in cattle fed low-quality tropical forage and supplemented with nitrogenous compounds Revista Brasileira de Zootecnia, v.38, p.560-569, 2009.

SAMPAIO, C.B.; DETMANN, E.; VALENTE, T.N.P. et al. Evaluation of fecal recovering and long term bias of internal and external markers in a digestion assay with cattle. Revista Brasileira de Zootecnia, v.40, p.174-182, 2011.

SILVA, D.J.; QUEIROZ, A.C. Análises de alimentos. Métodos químicos e biológicos. 3.ed. Viçosa, MG: Editora UFV, 2002. 235p.

UDÉN, P.; PARRA, R.; Van SOEST, P.J. Factors influencing reliability of the nylon bag technique. Journal of Dairy Science, v.57, p.622-622, 1974.

UDÉN, P.; Van SOEST, P.J. Investigations of the in situ bag techique and a comparison of fermentation in heifers, sheep, ponies and rabbits. Journal of Animal Science, v. 58 , p.213-221, 1984

VALENTE, T.N.P.; DETMANN, E.; VALADARES FILHO, S.C. et al. In situ estimation of indigestible compounds contents in cattle feed and feces using bags made from different textiles. Revista Brasileira de Zootecnia, v.40, p.666-675, 2011a.

VALENTE, T.N.P.; DETMANN, E.; VALADARES FILHO, S.C. et al. Avaliação dos teores de fibra em detergente neutro em forragens, concentrados e fezes bovinas moídas em diferentes tamanhos e em sacos de diferentes tecidos. Revista Brasileira de Zootecnia, v.40, p.1148-1154, 2011b. 
Van HELLEN, R.W.; ELLIS, W.C. Samples container porosities for rumen in situ studies. Journal of Animal Science, v.44, p.141-146, 1977.

Van MILGEN, J.; MURPhY, M.R.; BERGER, L.L. et al. A compartmental model to analyze ruminal digestion. Journal of Dairy Science, v.74, p.2515-2529, 1991.

Van SOEST, P.J. Nutritional ecology of the ruminant. 2.ed. Ithaca: Cornell University Press, 1994. 476p.
VANZANT, E.S.; COCHRAN, C.; TITGEMEYER, E.C. Standardization of in situ techniques for ruminant feedstuff evaluation. Journal of Animal Science, v.76, p.2717-2729, 1998.

VARVIKKO, T.; VANHATALO, A. The effect of differing types of cloth and of contamination by non-feed nitrogen on intestinal digestion estimates using porous synthetic-fibre bags in a cow. British Journal of Nutrition, v.63, p.221-229, 1990. 